\title{
ESP Course Evaluation of Business Communication for Masters in Commerce of a Pakistani University
}

\author{
Aamir Aziz ${ }^{1}$ \& Mamuna Ghani ${ }^{2}$ \\ ${ }^{1}$ Department of English, Government College of Commerce Sahiwal, Pakistan \\ ${ }^{2}$ Dean Faculty of Arts \& Chairperson Department of English, The Islamia University of Bahawalpur, Pakistan \\ Correspondence: Aamir Aziz, Department of English, Government College of Commerce, Liaqat Road Sahiwal, \\ Pakistan. E-mail: mianaamiraziz@hotmail.com
}

Received: May 8, 2017 Accepted: June 5, 2017 Online Published: July 26, 2017

doi:10.5539/ijel.v7n5p65 URL: http://doi.org/10.5539/ijel.v7n5p65

\begin{abstract}
English is the Language of globally expanding world of trade and commerce. English for Specific Purposes (ESP) is time-honored area of English Language Teaching (ELT), and it is by a long way at variance from General English (GE) because of its practical efficacy and learner centered approach. The need of ESP (Business Communication) at post-graduate colleges of commerce and departments of commerce of universities at master's level classes is to outfit the students with most recent communicative trends so that they can become resourceful members of some reputed business house. In the present study the researchers have done ESP course evaluation of the current course of Business Communication for Masters in Commerce classes of Bahauddin Zakariya University, Multan. This course is taught at public and private sector post-graduate colleges of commerce affiliated with the university in the first year of two year master's degree program. For this purpose the researchers have used questionnaire for the students and interview for the teachers. After analysis of results, the current study presents the conclusion that the current course of Business Communication is unable to fulfill all the professional needs of the students and is also unable to link theory with practice. It needs improvement having in view the modern tendency in the field of Business Communication, the needs of the future experts and the requirements of national and international business concerns.
\end{abstract}

Keywords: English for specific purposes (ESP), Business Communication, needs analysis, course evaluation

\section{Introduction}

Coping with the pace and challenges of globalization, technological changes and financially viable developments in the world, nations are experiencing thorough transformations in cultural, lingual, political, economic and educational systems. Under the splendid global changes, development in English language learning is not exceptional and had to see limelight in becoming a connection across many borders in international communication counting Pakistan as well.

According to Harmer (2007), we are the dwellers of this global village, having different national and lingual backgrounds. At every moment of our way of life, we are in need to share feelings and attitudes and pass on information to others. For this purpose, English is the only global language and vehicle of international communication.

It is an official language of Pakistan along with Urdu but most of the correspondence is being done in English. It has become our life style. It is widely used in education, business, trade and commerce, Economics, information technology, medicine, engineering, advertisements, print and electronic media, parliamentary affairs, judicial proceedings, research and in all walks of our daily life as well. Those who are well versed in English are considered cultured and elite. They have more opportunities to grow and play influential role in the society.

The importance of Business Communication (B.C) courses for commerce and business students is order of the day and their need is very high for the development of commerce, trade, industry and economy and effective outcome almost in every area of our social activity. Communication in the success of any business or to succeed in every sphere of life is like backbone. The present study is significant for future course designers. It will help them to plan further courses that may fulfill the professional needs of the students 


\subsection{Focus of the Study}

In the present study the researchers' centre of attention is ESP course evaluation of the current course of Business Communication (B.C) for Masters in Commerce classes of Bahauddin Zakariya University (B.Z.U.), Multan. The course under discussion is taught in the first year of two years M.Com degree program at public and private sector post-graduate colleges of commerce affiliated with B.Z.U, Multan.

\section{Literature Review}

In this part of the paper, the difference between ESP and EGP/GE, theories related to ESP, needs analysis, course/syllabus design and course evaluation, are discussed.

With the globalization of trade and commerce, business and industry, science and technology, there is the need of an international language for experts to interact. English language emerged as an international language. In this scenario English for specific purposes appeared on the horizon of English Language Teaching (ELT) to satisfy the trade specific language needs of the learners. In the area of English Language Teaching (ELT), Business Communication is an offshoot of English for specific purposes (ESP).

\subsection{The World of ELT}

According to Hutchinson \& Waters (1991), the world of ELT is a dynamic world. A few decades back its dwellers were divided in to two tribes i.e., English as a Foreign Language (EFL) and English as a second Language (ESL) only. They were living in quite harmony, having the same destination of literature and grammar.

After the World War-II, the newly emerging world of trade and commerce, business and industry, science and technology began to surround the world of ELT. Few inhabitants of this world travelled to the newly maturing world and overwhelmed to see the great change and found them misfit there.

With the passage of time a novel and prolific country of ESP appeared on the map of this world with its different parts as EST, EBE, EAP, EOP, EVP, VESL etc.

\subsection{Distinction between EGP and ESP}

The aim of learning English for general purpose (EGP) is to prepare the learners to qualify examinations of general category whether the aim of learning English for specific purposes (ESP) is to prepare the learners as per their professional needs i.e., of a manager, a banker, a trader, a marketer, a technician, a doctor, a nurse, a researcher, an engineer, an auditor, an accountant etc. Here the center of attention is on the exclusive needs of the learners and the demands of their respective professions.

In this context Strevens (1980) point of view also favors the differences between EGP and ESP. He opines that EGP may be regarded "English of the Exam" and main focus of ESP is on the learners' needs. He further expounded that the following key features of ESP courses are at variance from EGP courses.

ESP courses are:

- $\quad$ Devised to meet the learner's particular needs

- Related in themes and topics to designate occupation: or areas of study

- $\quad$ Selective (i.e., not general) as to content

- When indicated restricted as to the language "skills" included.

Nowadays, English is the only medium of world communication and it is utmost necessary for every profession. For effective and successful communication, the students of various professional areas are in need of ESP courses. The main features of these courses are "sense of purpose and the sense of vocation" (Harding, 2007, p. 6). These features clearly reflect the students' communicative needs in their concerned professions. Harding (2007, p. 6) further asserts that "in ESP- English for specific purposes- the purpose for learning the language is paramount and relates directly to what the learners needs to do in their vocation or job".

\subsection{English for Specific Purposes (ESP)}

ESP is the core of ELT. English for specific (or special, specified, special) purposes is the kind of language learning, having its focus on all aspects of language related to an exclusive area of human interaction (Wright, 1992 , p. 3). At the present time, it is becoming exceedingly popular in the world. It plays a pivotal role in learning of students who already having some knowledge of English i.e., from higher secondary to higher level for the fulfillment of their specific/special needs with practical outcome. It is the key feature of ESP courses that the focal-point is learner and their main center of attention is the workplace needs of the learners. 
Scholars and researches in the area of ESP narrated in simple and clear terms that it is language for some specific purpose. So far as characteristics of ESP are Concerned Strevens (1988) describes following four absolute and two variable characteristics.

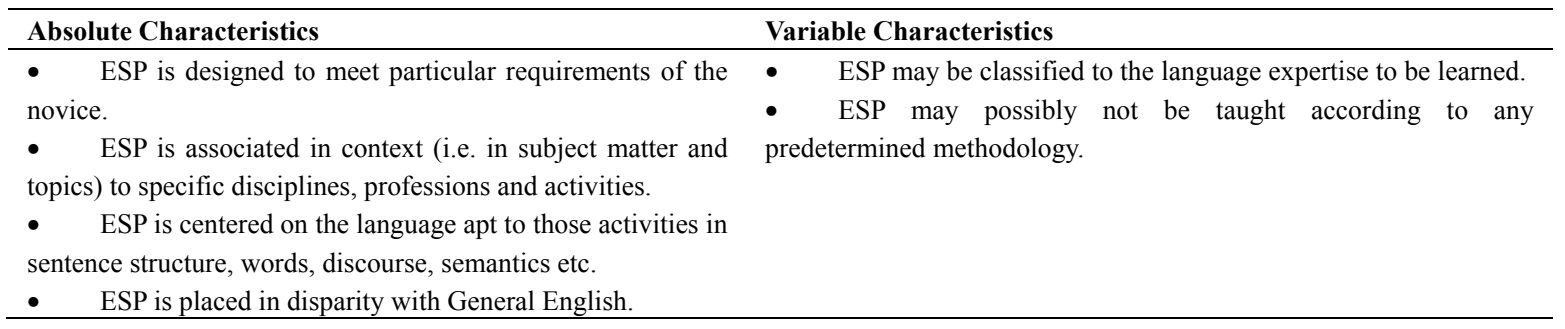

However Dudley-Evans and St. John (1998, p. 4) ten years afterward reworked the characteristics as under.

\begin{tabular}{|c|c|}
\hline Absolute Characteristics & Variable Characteristics \\
\hline $\begin{array}{l}\text { - ESP is defined to meet definite requirements of the } \\
\text { learners. } \\
\text { - ESP makes use of fundamental methodology fitting to } \\
\text { these activities of the discipline it serves. } \\
\text { - ESP is centered on the language fitting to these activities } \\
\text { in connection to syntax, terminology, register, study skills, } \\
\text { discourse and genus. }\end{array}$ & $\begin{array}{l}\text { - ESP may be associated to or planned for particular disciplines. } \\
\text { - } \quad \text { ESP may use, in specific teaching state of affairs, a diverse process } \\
\text { from that of General English. } \\
\text { - ESP is likely to be designed for mature learners, either at a tertiary } \\
\text { level institution or in a skilled work state of affairs. It could, however, be } \\
\text { for learners at secondary school level. } \\
\text { - ESP is usually planned for intermediate or higher students. } \\
\text { Mainly ESP courses presume some fundamental knowledge of the } \\
\text { language scheme. }\end{array}$ \\
\hline
\end{tabular}

\subsubsection{Types of ESP}

Hutchinson and Waters (1991) divided it further and represented through a "Tree of ELT". According to them the main kinds are:

- $\quad$ EST (English for Science and Technology)

- $\quad$ EBE (English for Business and Economics)

- $\quad$ ESS (English for the Social Sciences)

Each of the above mentioned kind is further subdivided in to

- EAP (English for Academic Purposes)

- $\quad$ EOP (English for Occupational Purposes) 


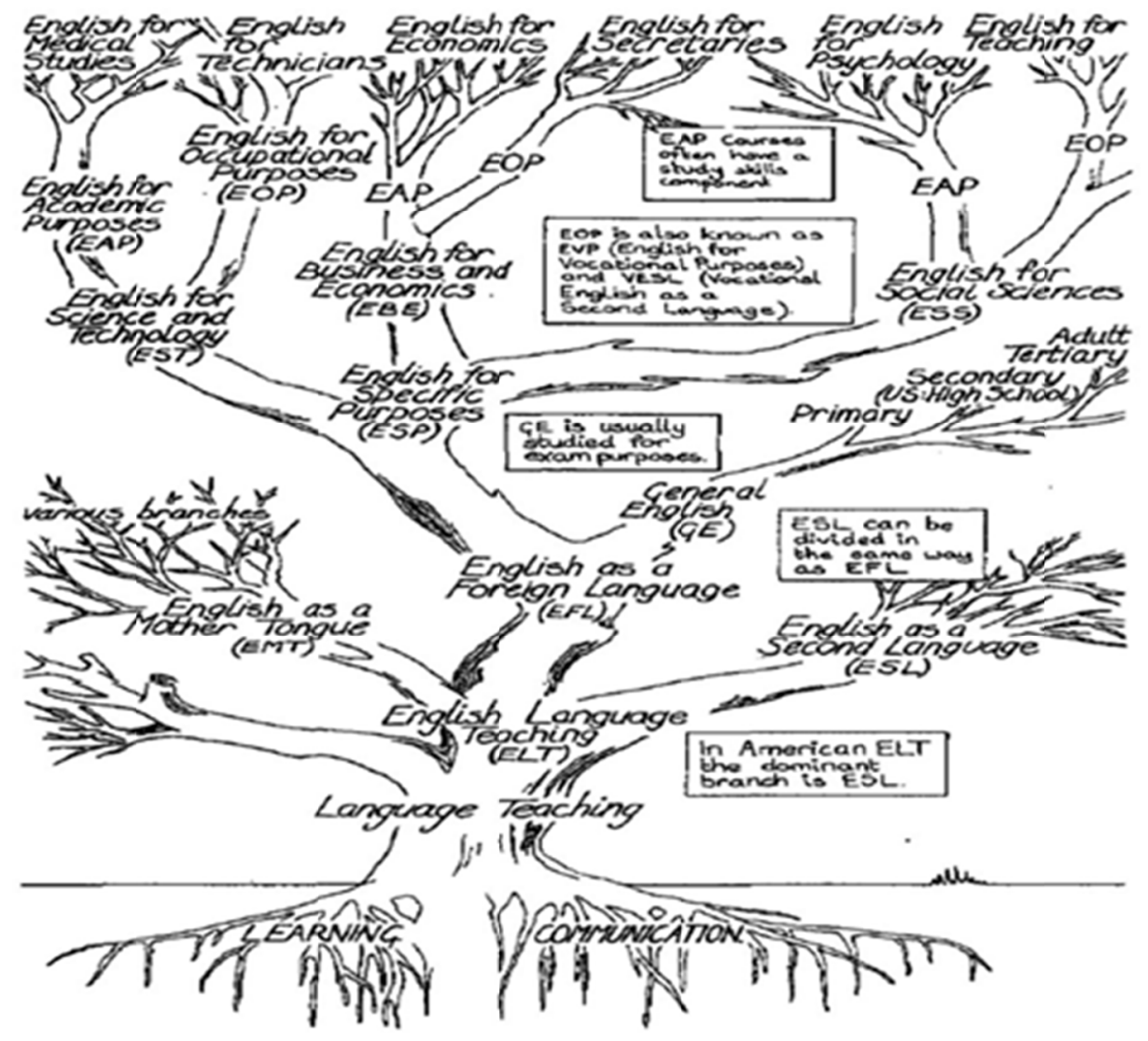

Figure 1. The tree of ELT (Hutchinson and Waters, 1991, p. 17)

\subsection{ESP Course Evaluation}

Williams (1983), based evaluation process on current procedure, direction to non-native teachers, needs of second language learners and applicability to the sociocultural environment. While Killen (2002), described evaluation "a systematic, purposeful process of studying, reviewing, and analyzing data gathered from multiple sources in order to make informed decisions about a program".

The purpose of ESP Course evaluation is to know either the course fulfills the objectives for which it is designed to achieve. The results of the course evaluation process tell about its effectiveness, the need of revision of the course and in future they guide the course designers.

Course evaluation also plays a key role in any social set up because it gives value to the opinion of different stakeholders i.e., learners, teachers, administration, sponsors etc.

\section{Research Design}

In this study the researchers have used the triangulation method and triangulation place for data collection. The data has been accumulated through qualitative and quantitative techniques because "a single approach to analyze the language needs of the students in any context yields a limited data" (Cohen, Manion, \& Morrison 2000).

In this context Richards (2001, p. 297) opines that "in language program evaluation both quantitative and qualitative approaches to collecting information are needed, because they serve different purposes and can be used to complement each other."

The researchers espoused the following research tools for evaluation of the course of Business Communication for Masters in Commerce classes.

- Questionnaires completed by Students of M.Com (Part-II)

- Interviews of English Language Teachers

The purpose of questionnaire was to evaluate the course of Business Communication in the light of the opinion of senior students of M.Com Part-II who had studied the subject in their first year of two years M.Com. All the 
students of M.Com Part -II, studying in different public and private sector postgraduate colleges of commerce affiliated with B.Z.U. Multan were population for this study. The questionnaire was pilot tested because it was "essential to identify ambiguities and other problems before the questionnaire administered" (Richards, 2001, p. 60). After the pilot test the questionnaire was administered to 200 students of M.Com Part-II in four different colleges while randomly selecting 50 male and female students from randomly selected one public and private sector postgraduate college of commerce of Sahiwal and one public and one private sector postgraduate college of commerce of Multan to complete this questionnaire. The questionnaire was developed by the researchers while using the Likert scale checklist.

For effective course evaluation and syllabus design opinion of English language Teachers is very important because they are teaching Business Communication and properly know the needs of students and short comings in the course. The purpose of interviews was to strengthen the validity of research. In this regard structured interviews of 20 teachers were conducted. The teachers are serving in 10 different public and private sector colleges of commerce of Sahiwal and Multan, affiliated with B.Z.U, Multan.

\section{Data Analysis and Discussion}

This part of the study presents the analysis and interpretation of the data to reach the outcome and to attain the research goals. The analysis of the data collected with the help of diverse sources is meticulously elucidated in the coming part of the paper. The quantitative data collected from close ended questions of questionnaires, entered in SPSS-17 (VERSION) and frequency tot ups, percentages and mean were applied. For sake of more clarity tables are used to present the results. On the other hand the data gathered from open ended questions and interviews were analyzed qualitatively.

\subsection{Analysis of the Questionnaire}

The questionnaire was administered among students of M.Com Part-II in person. These students have read Business Communication in their M.Com Part-I.

The results are discussed as under:

200 respondents took part in this study among them were 140 male and 60 female students. They belonged to four different post-graduate colleges of commerce. They were 21 to 23 years old. They have studied Business Communication in M.Com Part-I.

Table 1. Course contents

\begin{tabular}{llllllll}
\hline S. No. & Questionnaire Items & SA & A & UD & DA & SDA & Mean \\
\hline 1 & The quality of the course content is good. & 10 & 53 & 18 & 81 & 38 & 3.42 \\
2 & The Course content is valuable and worth learning. & 7 & 49 & 51 & 51 & 42 & 3.36 \\
3 & The Course contents are well organized. & 2 & 31 & 84 & 60 & 23 & 3.35 \\
4 & The Course contents fulfill all the professional needs. & 0 & 13 & 28 & 92 & 67 & 4.06 \\
5 & The Course contents add in my score of knowledge. & 11 & 50 & 60 & 37 & 42 & 3.25 \\
\hline
\end{tabular}

Item 1 shows the analysis of the quality of course content. $10(5 \%)$ respondents are strongly agree, $53(26.5 \%)$ respondents are agree, $18(9 \%)$ respondents are undecided, $81(40.5 \%)$ respondents are disagree while $38(19 \%)$ respondents are strongly disagree. The total mean are 3.42. The analysis shows that majority of the respondents do not find the quality of course content good.

Items 2 shows the analysis of the question about the value and learn ability of course content. 7 (3.5\%) respondents are strongly agree, $49(24.5 \%)$ respondents are agree, $51(25.5 \%)$ respondents are undecided, 51 $(25.5 \%)$ respondents are disagree while $42(21 \%)$ respondents are strongly disagree. The total mean are 3.36 . The analysis shows that majority of the respondents do not find the course content valuable and worth learning.

Item 3 shows the analysis of the question about the organization of course content. $2(1 \%)$ respondents are strongly agree, $31(15.5 \%)$ respondents are agree, $84(42 \%)$ respondents are undecided, 60 (30\%) respondents are disagree while $23(11.5 \%)$ respondents are strongly disagree. The total mean are 3.35 . The analysis shows that majority of the respondents do not find the course content well organized.

Item 4 shows the analysis of the question about the fulfillment of professional needs. $13(6.5 \%)$ respondents are strongly agree, 28 (14\%) respondents are undecided, $92(46 \%)$ respondents are disagree while $67(33.5 \%)$ respondents are strongly disagree. The total mean are 4.06 . The analysis shows that majority of the respondents do not find the course content is able to fulfill all the professional needs of the students. 
Item 5 shows the analysis of the question about the addition in the score of knowledge. $11(5.5 \%)$ respondents are strongly agree, $50(25 \%)$ respondents are agree, $60(30 \%)$ respondents are undecided, $37(18.5 \%)$ respondents are disagree while $42(21 \%)$ respondents are strongly disagree. The total mean are 3.25 . The analysis shows that majority of the respondents are undecided but there is still a higher ratio of those who are disagree and strongly disagree that course content add in the score of knowledge.

Table 2. Skill improvement

\begin{tabular}{llllllll}
\hline S. No. & Questionnaire Items & SA & A & UD & DA & SDA & Mean \\
\hline 1 & The course improved my reading skill. & 35 & 67 & 47 & 49 & 2 & 2.58 \\
2 & The course improved my writing skill. & 31 & 61 & 60 & 43 & 5 & 2.65 \\
3 & The course improved my speaking skill. & 3 & 15 & 45 & 85 & 52 & 3.86 \\
4 & The course improved my listening skill & 2 & 31 & 48 & 73 & 46 & 3.65 \\
5 & The course improved my report writing skill & 16 & 75 & 55 & 42 & 12 & 2.79 \\
\hline
\end{tabular}

Item 1 shows the analysis of the question about improvement in reading skill. 35 (17.5\%) respondents are strongly agree, $67(33.5 \%)$ respondents are agree, 47 (23.5\%) respondents are undecided, $49(24.5 \%)$ respondents are disagree while $2(1 \%)$ respondents are strongly disagree. The total mean are 2.58 . The analysis shows that majority of the respondents are agree regarding the question but there is a higher ratio of those who are undecided and disagree.

Item 2 shows the analysis of the question about improvement in writing skill. 31 (15.5\%) respondents are strongly agree, $61(30.5 \%)$ respondents are agree, 60 (30\%) respondents are undecided ,43 (21.5\%) respondents are disagree while $5(2.5 \%)$ respondents are strongly disagree. The total mean are 2.65 . The analysis shows that majority of the respondents are agree regarding the question but there is a very close ratio of those who are undecided and a high ratio of disagree.

Item 3 shows the analysis of the question about improvement in speaking skill. $3(1.5 \%)$ respondents are strongly agree, $15(7.5 \%)$ respondents are agree, $45(22.5 \%)$ respondents are undecided, $85(42.5 \%)$ respondents are disagree while $52(26 \%)$ respondents are strongly disagree. The total mean are 3.86 . The analysis shows that majority of the respondents are disagree and strongly disagree regarding the question, there is a very little ratio of those who are agree and strongly agree.

Item 4 shows the analysis of the question about improvement in listening skill. $2(1 \%)$ respondents are strongly agree, $31(15.5 \%)$ respondents are agree, $48(24 \%)$ respondents are undecided, $73(36.5 \%)$ respondents are disagree while $46(23 \%)$ respondents are strongly disagree. The total mean are 3.65 . The analysis shows that majority of the respondents are disagree and strongly disagree regarding the question, there is a little ratio of those who are agree and strongly agree.

Item 5 shows the analysis of the question about improvement in report writing skill. $16(8 \%)$ respondents are strongly agree, $75(37.5 \%)$ respondents are agree, $55(27.5 \%)$ respondents are undecided, $42(21 \%)$ respondents are disagree while $12(6 \%)$ respondents are strongly disagree. The total mean are 2.79 . The analysis shows that majority of the respondents are agree regarding the question, but there is a high ratio of those who are undecided and disagree.

Table 3. Participation of students

\begin{tabular}{llllllll}
\hline S. No. & Questionnaire Items & SA & A & UD & DA & SDA & Mean \\
\hline 1 & I actively participated in the course. & 32 & 86 & 48 & 26 & 8 & 2.46 \\
2 & I made progress in this course. & 32 & 69 & 63 & 33 & 3 & 2.53 \\
3 & I learned new things in the course. & 11 & 27 & 42 & 77 & 43 & 3.57 \\
4 & The total hours for this course are sufficient. & 15 & 69 & 59 & 42 & 15 & 2.86 \\
5 & I am satisfied with the present course. & 2 & 11 & 28 & 69 & 90 & 4.17 \\
\hline
\end{tabular}

Item 1 shows the analysis of the question about active participation of students in the course. $32(16 \%)$ respondents are strongly agree, $86(43 \%)$ respondents are agree, $48(24 \%)$ respondents are undecided, $26(13 \%)$ respondents are disagree while $8(4 \%)$ respondents are strongly disagree. The total mean are 2.46 . The analysis shows that majority of the respondents are agree as regards their active participation in the course.

Item 2 shows the analysis of the question about students' progress in the course. $32(16 \%)$ respondents are 
strongly agree, $69(34.5 \%)$ respondents are agree, 63 (31.5\%) respondents are undecided, 33 (16.5\%) respondents are disagree while $3(1.5 \%)$ respondents are strongly disagree. The total mean are 2.53 . The analysis shows that majority of the respondents are agree concerning their progress in the course but there is a high ratio of those who are undecided.

Item 3 shows the analysis of the question about learning of new things in the course. $11(5.5 \%)$ respondents are strongly agree, $27(13.5 \%)$ respondents are agree, $42(21 \%)$ respondents are undecided, 77 (38.5\%) respondents are disagree while $43(21.5 \%)$ respondents are strongly disagree. The total mean are 3.57 . The analysis illustrates that greater part of the respondents are disagree and strongly disagree concerning the learning of new things in the course.

Item 4 shows the analysis of the question whether the total hours of the course are sufficient. 15 (7.5\%) respondents are strongly agree, $69(34.5 \%)$ respondents are agree, $59(29.5 \%)$ respondents are undecided, 42 (21\%) respondents are disagree while $15(7.5 \%)$ respondents are strongly disagree. The total mean are 2.86 . The analysis illustrates that greater part of the respondents are agree but there is a high value of undecided and disagree respondents.

Item 5 shows the analysis of the question on satisfaction of respondents with the present course. Only $2(1 \%)$ respondents are strongly agree, $11(5.5 \%)$ respondents are agree, $28(14 \%)$ respondents are undecided while 69 $(34.5 \%)$ respondents are disagree and $90(45 \%)$ respondents are strongly disagree. The total mean are 4.17 . The analysis illustrates that the greater part of the respondents are dissatisfied with the present course.

Table 4. Learning outcomes

\begin{tabular}{llllllll}
\hline S. No. & Questionnaire Items & SA & A & UD & DA & SDA & Mean \\
\hline 1 & The Course developed independent thinking. & 5 & 23 & 56 & 86 & 30 & 3.56 \\
2 & The Course developed critical judgment. & 0 & 17 & 64 & 89 & 30 & 3.66 \\
3 & The Course developed group work ability. & 0 & 18 & 41 & 75 & 66 & 3.94 \\
4 & The Course developed the ability to link theory to practice. & 0 & 13 & 46 & 62 & 79 & 4.06 \\
5 & The course developed analytical ability & 3 & 17 & 31 & 55 & 94 & 4.10 \\
\hline
\end{tabular}

Item 1 shows the analysis of the question about the development of independent thinking. Only 5 (2.5\%) respondents are strongly agree, $23(11.5 \%)$ respondents are agree, $56(28 \%)$ respondents are undecided while 86 (43\%) respondents are disagree and $30(15 \%)$ respondents are strongly disagree. The total mean are 3.56 . The analysis illustrates that the greater part of the respondents i.e. $86(43 \%)$ do not think that the course develops independent thinking.

Item 2 shows the analysis of the question concerning development of critical judgment. Only 17 (8.5\%) respondents are agree, $64(32 \%)$ respondents are undecided while $89(44.5 \%)$ respondents are disagree and 30 $(15 \%)$ respondents are strongly disagree. The total mean are 3.66 . The analysis illustrates that the greater part of the respondents i.e., 89 (44.5\%) do not think that the course develops critical judgment.

Item 3 shows the analysis of the question concerning development of group work ability. Only 18 (9\%) respondents are agree, $41(20.5 \%)$ respondents are undecided while $75(37.5 \%)$ respondents are disagree and 66 (33\%) respondents are strongly disagree. The total mean are 3.94 . The analysis illustrates that the greater part of the respondents i.e., $75(37.5 \%)$ and $66(33 \%)$ do not think that the course develops group work ability.

Item 4 shows the analysis of the question concerning the link between theory and practice. Only 13 (6.5\%) respondents are agree, $46(23 \%)$ respondents are undecided while $62(31 \%)$ respondents are disagree and 79 $(39.5 \%)$ respondents are strongly disagree. The total mean are 4.03 . The analysis illustrates that the greater part of the respondents i.e., $62(31 \%)$ and $79(39.5 \%)$ do not think that the course link theory to practice.

Item 5 shows the analysis of the question about improvement in listening skill. $3(1.5 \%)$ respondents are strongly agree, $17(8.5 \%)$ respondents are agree, $31(15.5 \%)$ respondents are undecided, $55(27.5 \%)$ respondents are disagree while $94(47 \%)$ respondents are strongly disagree. The total mean are 4.10 . The analysis shows that majority of the respondents are disagree and strongly disagree regarding the question, there is a very little ratio of those who are agree and strongly agree.

The next four questions of the questionnaire are open ended questions. They are interpreted here one after another.

The respondents are asked about the best features of the course. According to their responses the best features of 
the course are report writing, letter writing, memo writing, grammar and writing skill.

Next the respondents are asked about the addition of new topics to improve the course. According to them inclusion of topics as presentation skill, speaking skill, listening skill, creative writing, problem solving skill, pronunciation drills, telephonic conversation, customer dealing, group work, team building, office decorum, work ethics, decision making and conflict resolution can improve the course.

Next the respondents are asked about the use of $\mathrm{A} / \mathrm{V}$ aids. According to them no $\mathrm{A} / \mathrm{V}$ aids are used during the lectures, rather they emphasize the use of $\mathrm{A} / \mathrm{V}$ aids.

Next the respondents are asked about the technology based learning. Almost all the respondents favor the use of technology in the course of Business Communication. They are of the opinion that the use of technology will motivate them and sharpen their learning.

\subsection{Analysis of the Interview}

The researchers conducted structured interviews with twenty faculty members of departments of English of various public and private sector post-graduate colleges of commerce. The analysis of the responses of English Language Teachers is presented here. The first three questions deal with professional details of the respondents.

So far as the question regarding experience is concerned ten respondents had 10-15 years experience, six respondents had 7-10 years experience while four respondents had 3-6 years teaching experience.

The next question is about qualification. All the respondents had done masters in English Literature while four of them had also done post-graduate diploma in Teaching of English as a Foreign Language (TEFL) along with masters degree.

The next question is about trainings. Five of the respondents had received training in ELT while eight of them had received training in Pedagogical skills.

The rest of the questions are in connection with course evaluation. In response to the question regarding fulfillment of professional needs, fourteen respondents said that the present course did not fulfill the professional needs of the students. They are of the opinion that the course is just beginners level. It is not up to the level of post-graduate program of studies. While four respondents are of the view that the course to some extent fulfills the professional needs and two respondents are of the view that the course fulfills the professional needs of the students.

The next question is about students' interest in the course. Twelve respondents pointed out that students are showing lack of interest in the course while four of them said that the students are taking a little bit interest in the course and the remaining four said that students are taking in the course.

The next question is about students' active participation in the course. Ten respondents said that students did not actively participate in the course while other ten said that they actively participate in the course.

The question is about students' eagerness to learn B.C. Fifteen respondents said that students are not eager to learn B.C. because the present course did not offer novel ideas. Three respondents said that the students' level of eagerness is average while two respondents said that students are eager to learn B.C.

The next question is about deficiencies in the students. The respondents mentioned that the faulty pronunciation, lacking presentation skill, inability to group work, inability to communicate effectively, inability to write correctly, lacking analytical ability and lacking interview skill are some of the deficiencies among students.

As regards the next question about students' level of competency in English is concerned all the respondents are agreed that their level of competency in English is average.

The next question is regarding technology based language teaching and learning. All the respondents are agreed that technology based language teaching and learning is very crucial. To meet the daring challenges of global job market and to equip the learners with latest technological techniques in the field of B.C., it is utmost necessary that technology based language teaching and learning should be introduced in the curriculum.

As regards the question regarding collective impression of the course is concerned, seventeen respondents said that the course is not up to the mark as it is meant for the masters level classes. They are further of the view that it seemed that the course is designed haphazardly. Other three are of the view that the course is good.

So far as the next question suggestions regarding improvement of the course is concerned, nineteen respondents said that the course acutely needs improvement. Only one respondent is of the view that there is no need of improvement of the course and he presents the reason that he is among one of the course designers so he does not feel any need of improvement. The respondents suggested the addition of the topics as decision making, 
work ethics, intercultural communication, presentation skill, interview skill, leadership in communication, self-management, dealing with conflict, interpersonal communication, communication and change, telephonic communication and scholarly essays of renowned writers and philosophers as Bacon, Ruskin, and Carlyle etc. for the improvement of critical thinking can improve the course.

\section{Conclusions}

Keeping in view the data from the students' questionnaire and teachers' interview, the conclusion may be drawn that the current course is unable to fulfill the professional needs of the learners and the requirements of the day to day market. The course ignores the most important skills and is a traditional one. It does not offer interesting and novel ideas. Most of the course is theoretical in nature it should focus on practical aspects. It totally ignores the use of technology which is the latest requirement of language learning and teaching. Further the course does not develop learner autonomy which is crucial in the present world.

\section{Recommendations}

The present study recommends that:

- The course may fulfill the needs of the global market.

- The course may contain creative and innovative ideas of the concerned field.

- The students are prepared in four communication skills.

- Technology based language learning and teaching may be introduced.

- The teaching faculty may be equipped with latest techniques of communication.

- All the stakeholders may be involved in the process of course design.

- The course may be evaluated on regular basis.

- The course may fulfill the professional needs of the learners.

\section{References}

Chohen, L., Manion, L., \& Morrison, K. (2000). Research Methods in Education (5th ed.). London: Routlege Falmer. https://doi.org/10.4324/9780203224342

Dudly-Evans, T., \& St. John, M., (1998). Developments in ESP: A Multi-Disciplinary Approach. Cambridge: Cambridge University Press.

Harding, K. (2007). English for Specific Purposes. New York: Oxford.

Harmer, J. (2007). The Practice of English Language Teaching. China: Pearson Education Limited.

Hutchinson, T., \& Waters, A. (1991). English for Specific Purposes. Cambridge: Cambridge University Press.

Killen, J. (2002). Assessing Impact: Evaluating Staff Development. Oxford, OH: National Staff Development Council.

Richards, J. C. (2001). Curriculum development in Langue Teaching. Cambridge: Cambridge University Press. https://doi.org/10.1017/CBO9780511667220

Strevens, P. (1980). Teaching English as an International Language: From Practice to Principle. Oxford: Pergamon Press.

Strevens, P. (1988). ESP after twenty years: A re-appraisal. In M. Tickoo (Ed.), ESP: State of the Art (pp. 1-13). Singapore: SEAMEO Regional Centre.

Williams, D. (1983). Developing criteria for textbook Evaluation. ELT Journal, 37, 251-255. https://doi.org/10.1093/elt/37.3.251

Wright, C. (1992). The Benefits of ESP. Cambridge Language Consultants. Retrieved from www.camalang.com

\section{Copyrights}

Copyright for this article is retained by the author(s), with first publication rights granted to the journal.

This is an open-access article distributed under the terms and conditions of the Creative Commons Attribution license (http://creativecommons.org/licenses/by/4.0/). 